\title{
The Problems of Rebuilding a State in Iraq 2003-2015
}

\author{
Murad A. Abbas, Radhi S. Jassam \\ Department of Political Thought, International Studies, University of Baghdad, Baghdad, Iraq \\ Email: aliabbasmurad@yahoo.com, sameerjassm@yahoo.com
}

Received 27 March 2015; accepted 9 June 2015; published 12 June 2015

Copyright (C) 2015 by authors and Scientific Research Publishing Inc.

This work is licensed under the Creative Commons Attribution International License (CC BY). http://creativecommons.org/licenses/by/4.0/

(c) (i) Open Access

\section{Abstract}

The process of rebuilding the new state in Iraq has faced many internal and external problems. This study is going to focus on the internal problems; they are represented by the problem of national identity, setting the basis of the new Iraqi state, democracy, federalism, national reconciliation and governmental corruption. We selected those problems because we agreed with the consensus among Iraqi academic $\&$ political forces on attributing the continuity of instability $\&$ the increasing number of human casualties in Iraq to those specific problems. So, we think that solving those problems in accordance with strong national laws will lead to secure the building of Iraqi democratic state capable of making peaceful coexistence among its components based on their public acceptance to principles of liberty, citizenship, equality, pluralism and the separation of powers.

\section{Keywords}

State, Authority, Rebuilding, Identity, Fedralism, Reconciliation, Corruption

\section{Introduction}

The rebuilding of the new Iraqi state since April 2003 is considered as one of the major socio-political projects ever to be done in Iraq since the creation of the stat in 1921. The rebuilding project requires:

1) Destruction of all the socio-political infra-structures of not just being the old state, but being the Iraqi society as a whole;

2) Changing the nature and philosophy of the old state and building a new philosophy suitable to all new socio-political forces that have taken control of the administration after the establishment of the Iraqi consultative ruling counsel by Paul Bremer, the first American ruler of Iraq in May of 2003.

Iraq has faced internal and external problems in the process of rebuilding its state. This study is going to focus 
on the internal ones; those problems are represented by the problem of national identity, setting the basis of the new Iraqi state, democracy, federalism, national reconciliation and governmental corruption. We selected those problems because we agreed with the consensus among Iraqi academic \& political forces on attributing the continuity of instability \& the increasing number of human casualties in Iraq to those specific problems. So, we think that solving those problems in accordance with strong national laws will lead to secure the building of Iraqi democratic state capable of making peaceful coexistence among its components on principles of liberty, citizenship, equality, pluralism \& the separation of powers.

\section{The Problem of National Identity}

The state of Iraq has been formed of three different \& separate local sub-states; all they had in common is being part of the Automan Empire. Therefore, Iraq in fact is considered a pluralist state which has faced problems concerning this pluralisms \& the identity they should share. The causes of these problems are not related to the heterogenic nature of the Iraqi society, but it is related to two different factors;

1) The dominations of the heterogenic factors on the homogeny \& integrative factors among the components of the Iraqi society;

2) The failure of all governmental \& private methods to manage the interactive relationship between the different social variation which have threatened the stability of the state $\&$ even its survivability.

The suffering of any state or society from the problem of the weakness or absence of a common identity does not make it a constant problem, this is because different identities could coexist \& interact peacefully (Huntington, 2004). Human groups could change their identities temporarily or even permanently, but under certain conditions:

- The recognition of the embracing dominant identity of the legitimacy \& the right of existence for all sub-identities ensuring that legally \& constitutionally;

- The recognition of each sub-identity of the legitimacy \& right of existence to all other sub-identities \& ensures that legally \& constitutionally;

- The realization of all sub-identities $\&$ their acceptance to the common needs, objectives $\&$ interests, within the framework of the embracing mother identity;

- The recognition of all sub-identities to the common threats \& dangers which have been faced within the framework of the embracing mother identity. The positive interaction between these sub-identities with the embracing mother identity is considered as a prerequisite to face these problems.

The mutual recognition of the identity $\&$ respect of its freedoms $\&$ rights represent the essence $\&$ common dominator among all those conditions. This recognition does not require cancelling sub-identities $\&$ at the same time does not block its integration in the political societal identity (the national identity). This kind of recognition would raise the status of the national identity. The most important conditions to achieve the Iraqi social consensus on the national identity are:

- The ability of the Iraqi national identity in achieving the actual national reconciliation, with itself first \& then, with all Iraqi societal sub-identities. Also, its ability to ensure the legal \& constitutional guarantees in order to achieve the equality among them in rights \& duties;

- The ability of the national identity in embracing the other Iraqi societal sub-identities through the actual application of ensuring interests $\&$ confidence building, which would make interdependence $\&$ the positive peaceful coexistence between the two types natural \& spontaneous.

Finally, those conditions could not be achieved, unless reconciliation with the self \& with others is accomplished in Iraq. Such a mission could never be achieved now, not only because of the rooted differences between the principles \& objectives of the social \& political powers in Iraq at the present time, but also because of the rooted differences between the principles \& objectives of the regional \& international powers which influence the internal Iraqi affair.

\section{The Problem of Setting the Basis of the New Iraqi State}

This problem has started with the declaration of Mr. Paul Bremer the formation of the Iraqi consultative ruling council, based on the relative representation of Iraqi components. The declaration included that the decisions must be made by consensus of all members of the council. This is considered as a right of veto to each member, 
and this means that each one of them is capable of stopping the government from doing its job.

This council was based on the percentage of each one of components of Iraqi society. This formula had become the basis for the actual practices of Iraq politics since then, and formed through five consecutive governments on that basis. This means that what has come to be applied is not a voting majority; rather, it has become democracy of consent, which has led to government of consent. Those governments have lost their nature of consent, and their ministers transferred it into a nature of intersection, which has paralyzed the real intention of work.

Many democratic governments, especially in Europe, have the nature of democratic consent and practice consensual democracy. Those governments have not faced the problems Iraqis are facing for the following facts:

- Their historical democratic heritage;

- Their cumulative practical experience;

- Their general agreement on basic national interests and principles.

Those facts are missing in the Iraqi governments after April 2003, which have led to weakness of its performance and the disfunctioning in pursuing its policies. This means that, good governance in Iraq need to have some of the previous facts; the weakness of Iraqi government has been reflected in the bad performance and its inability to solve the problems.

\section{The Problem of Democracy}

Achieving justice has been one of the most important human demands whether individually or collectively. This is because justice is considered as a precondition to achieve the basics of other human demands and to be the best mean to ensure the achievement of other human needs, and dealing with all aspects of the absence of justice in human life, which are represented by:

- The absence of political justice;

- The absence of social and legal justice;

- The absence of economic justice;

- The absence of cultural and the epistemological justice.

The absence of justice is a comprehensive and multi-dimensional problem, so, the settlement of this problem must be comprehensive and multi-dimensional (Dahl, 1964).

This could be applied to the state of Iraq which has a multi-ethnic religious sects and political movements. Iraqis have worked with their close friends on a very ambitious project to be achieved in such a country. To ensure justice, they need to apply all democratic means and techniques. In order to achieve such ambitious democratic project, Iraq and its close friends, need to remember that constitution have been known by Iraqis since the creation of the Iraqi state in 1921. Democracy was one of the basic principles of those constitutions whether permanent or temporally. The absence of democracy in Iraq is not due to constitutional causes, but it is a consequence of the bad implementation to those constitutional principles.

Other causes of the absence of democracy in Iraq would be:

- The absence or weakness of political participation of Iraqi civil society;

- Building democracy requires building of democratic citizen which in turn requires the building of plural types of institutions, which aims at the socialization of those citizens (Lijphart, 1977). Such a hard work could not be achieved by Iraqis alone, they need a real and standing commitment by its close friends, who have the required expertise, to achieve such a project and the right means to keep the Iraqis committed to such a work;

- Iraq is a rich country; this requires the government to balance between the political and social democracy. In addition, this imposes on its close friends to assist in the planning to build an open market economy, close to the European social justice system, which we think it would be more capable of achieving the interests of Iraq and its close friends. Sharing power in Iraq, need to be understood as none zero sum-game, and Iraqis need to be trained on understanding such a game by their close friends.

\section{The Problem of Federalism}

Federal system is one of the many types of political systems in the world, and it is just as good as other types of political systems. If needed then, it would be preferred on other systems. The federal system could be defined as a form reflecting the governmental structure and formation within a social group to achieve the differentiation 
between rulers and ruled, based on the constitutional distribution of authorities within these groups on two or more different (Duverger, 1958).

A study conducted by Watts, reaches to the conclusion that, public consent to the required political processes and values is more important than the legal and institutional legislation and structures of federal system (Watts, 2005). This public consent includes the satisfaction with the federal system, and accepting what comes out of this system of different identities, major and minor loyalties within the framework of the public acceptance to the common goals and policies which provide the basis to the parallel paths of the common rule.

The necessity, importance and value of the federal system highly appears in its ability in compromising between variations and unity, and by mixing between the elements of the governance of the units comprising federalism in many specific affairs, and common rule in other affairs. This will open the path broadly in front of leaders, rulers to innovate or to accept new form of innovation of federal techniques, capable of achieving the desired goals and avoid the probable risks, using the available capabilities, do the proper adjustment which requires the pragmatic assimilation to the facts and circumstances of their societies. This appears to be a necessity in the age of Globalization which has led to the rise of separate identities and deepens or more their attitudes toward independence.

The federal system is based on different regional, ethnic, cultural, and political basis. So, the federal system of Iraq is recognized by combining between ethnicity and regional basis. There is no problem raised on such situation in many states, but the problem rise in Iraq from the existence of many different future federal projects adopted by Arab political figures as well as political parties. That future projects are claimed to be based publicly on regional basis, but, in reality, they are based on cultural and regional-sectarian borders. The demanded federalism based now on Arabs as ethnic component has divided them in accordance with their religious groups $\&$ sectarian basis. This new reality includes two problems:

- Weakening of the Arabs of Iraq as major component into dividing them into conflicting sects, would enhance the capability of the Kurds as a second component of Iraq, despite the fact that, Kurds are also Muslims and belong to the Sunnies and Shiees sects at the same time;

- The creation of any future federal project would be either based on religious-sectarian, in which it would encourage the other Iraqi religious sects to create for each of them federal region since Iraq is comprised of many small religions and sects.

\section{The Problem of National Reconciliation}

Reconciliation means appeasement, compromise and agreement between conflicting parties, groups, etc. When the old state of Iraq collapsed in April 2003, what thought to be a harmonious Iraqi society, turned out to be a highly conflicted society. The social components of the state of Iraq entered in a communal, ethnic and sectarian struggle. In order to deal with such a situation, a reconciliation process needed to be conducted by governmental and non-governmental agencies. This process was not truly conducted by state agencies for different reasons.

The understanding of the paths of national reconciliation in Iraq requires the study of the role of governmental agencies since the creation of the first Iraqi authority under the rule of the occupation authority, until the end of the fourth elected government in 2014.

1) National Reconciliation during the stage of consultative Ruling council (C R C).

The (C R C) never deal with such a term. The reason is that, despite the total loss of a state security institutions, the Iraqi society was still quite and controlling their own affairs cooperatively. The $\mathrm{C} \mathrm{R} \mathrm{C} \mathrm{should} \mathrm{issue} \mathrm{an}$ initiative similar to the one of South Africa, in order to set future foundations of maintaining harmony among the components of Iraqi society.

2) National Reconciliation during the rule of the government of Mr. Ayad ALLAWY.

During that period, Secterial and communal violence have not erupted yet among the component of Iraqi society. But the government was very busy fighting elements defying the new government authority. Fighting such elements made Allawy lose his future political career. So, there was no real motive for Allawy to issue such an initiative of National Reconciliation.

3) National Reconciliation during the rule of the government of Mr. Ibrahim Al-jaafari May 2005-june 2006.

This stage of rule, had witnessed the first appearance of the internal tension and conflict. In February 2006 Sunni fanatics north of Baghdad exploded Holly Shrine of Shiaa. This event had led to a civil strife among Mus- 
lim sects in Iraq. In addition, this event made the Arab League to call for the participation in a conference held in Cairo inviting all representatives of Iraqi conflicting groups. The conference was under the patronage of former president of Egypt Mr. Husni Mubarak. The representatives of the permanent staffs at the Security Council attended the conference and many other representatives of others concerned states and groups. The Iraqi conflicting groups attending the conference agreed on ending the causes of conflicts in Iraq through the following of certain procedures. One of these would be the launching of National Reconciliation initiative. What happened after the end of the conference was that, all the Iraqi groups, weather governmental or nongovernmental forgot what they agreed upon during the conference and entered in a bloody period, which looked like a civil war.

4) National Reconciliation during the rule of the first government of Mr. Nory Al-Maliky June 2006-June 2010.

Mr. Al-Maliky is considered the first Iraqi rulers to deal seriously with the issue of National Reconciliation. He had to confront those who defy the authority militarily, and at the same time, setting the rules for the assimilation for all those who would like to abandon the use of weapon and join the political process in Iraq. On June 25 2006, he announced the initiation of the reconciliation program to deal with all the problems created by terrorism and administrative corruption (Annabaa.org, 2006). Iraqi parliament supported such a step and forms a committee to deal with such an issue. Mr. Akram AL Hakeem was the head of this committee and later, he became the first minister to such an issue in the modern political history of Iraq (State Ministry of National Dialogue Affairs, 2007, 2008). Due to the political and social complexities of the Iraqi political process, the ministry could not achieve any real success. Instead, they issued statements describing the progress of their work and mostly exaggerating that work (Edited Book, 2009).

The objectivity requires us to be fair in evaluating the work of reconciliation under Al Maliky's two term's administration:

- It is highly mistaken to hold AL Maliky government responsible for the failure of all the programs and policies of reconciliation. Other groups should bear a great share of the responsibility. The government of Mr. Maliky inherited from its predecessors and then passed to its successor Mr. Al-Abade, Many problems created by internal and external factors, which resulted in making conflicting circumstances and national fighting. Because of Mr. Maliky's policies in his second government, those problems have been broadened and deepened, causing the missing of many opportunities of achieving national reconciliation.

- Some of those major problems are:

1) The change of the previous Iraqi regime through a military act by a foreign power did not get the consensus of the Iraqi societal and political forces. This fact has led to the division among those forces, and this division has led or forced many of those forces to carry weapon and fight those forces that work on holding the authority and run the political regime. In order to achieve a real and transparent reconciliation process in Iraq, we should get rid of this division and prepare a fertile environment to make all societal and political forces trust each other and work together to achieve harmony which would be reflected in a good decisions for building a real state institutions.

2) The formation of the consultative Ruling Council (C R C) by the occupation authority on the basis of distributing powers among the ethnic, religious, and sectarian components of the Iraqi society, according to their shares in the society (the Quota principle) was one of the major causes of armed conflict after the year 2003. This decision was faced by three conflicting views. The first has received positions never dreamed of, and make it feel satisfied with such a decision. The second has felt a sever injustice inflicted on its people through losing much of its former power as well as losing many political posts in the present authority. The third view focused on the injustice, because they felt that, they have lost their national identity and the ignorance of the principle of the equality before the law for all Iraqi citizens. This means that, the feeling of injustice has never ended among the Iraqis after the fall of the old political regime, but, it has been transformed from one component to others, and just became deeper and broader and more severe than its old time.

The feeling of injustice has led to the increase of violence among the political components, between those who benefited and those who got dissatisfied by such a decision. Therefore, the Quota principle is considered to be as the second important cause of the civil violence in Iraq. We believed that, one of the most effective factors in stopping this violence is to end the Quota principle in administering the state of Iraq.

3) The achievement of the processes of writing and approving the Iraqi constitution under an environment of distrust and fear among its components, have contributed significantly to the violent conflict in the following 
years. Each party has sought to achieve its own interest on the interest of the other parties. They have made the process of amending the constitution almost out of question.

Many articles of the constitution and other laws should be amended such as, the article concerning the governorate of KARKUKE. The de-Bathification and the questioning and justice, the article concerning the relationship between the federal and regional governments, the problem of distributing power and authority between the parliament and the executive, the general pardon law, the problem of Iraqi identity and the relationship between religion and the state.

The rejection of the political regime or some of its active participants to amend those problems, or its inability to amend theme, even if it expressed its will to do that, would keep those problems unsolved and cause the continuation of the violent conflict, which would be a major impediment to achieve in the reconciliation process.

4) The rejection of the government, or some of its participating parties, to open a compromising dialogue with many of the opposing political forces despite the influence of those forces on the social and political life in Iraq, would keep those opposition forces active in the field against the government which would lead to delay or even stop the achievement of the national reconciliation process.

5) A total or partial rejection of many of those oppositions forces to start a compromising dialogue with the government, would have a negative impact on the achievement of the process of the national reconciliation.

6) The un-solving of many of the conflicting cases between the government and few of the oppositions forces such as (the awakening and support council, the employee of the dissolved institutions and the high ranking officials of the old regime) would delay or stop the achievement of the national reconciliation process.

7) The un-passing of the required legislations for the stability of life and the legitimacy of the political process in Iraq, such as (the law of political parties, press, the financial integrity of governmental and political parties officials, and independence and transparency of the judiciary, the professionalism and impartiality of security and military institutions) in such away, which would not lead to or prevent the achievement of the national reconciliation.

8) The dissatisfaction expressed by some of the political forces inside or outside the government concerning many passed legislation and the means to perform them in such a way, which would not lead to or, delay or prevent the achievement of the national reconciliation.

9) The unwillingness of many regional and international parties to achieve a comprehensive or partial reconciliation for different reasons. Therefore, they would interfere in the internal affairs of Iraq in such a way that would lead to delay or prevent the achievement of the national reconciliation.

10) The unsolved conflicting cases between the Iraqi government and many of the Arab and regional states, concerning the nature and the scope of the relations with the government of the United States of America and the neighboring countries, would push those states to achieve their interest through the intervention in the internal affairs of Iraq, in such a way that would lead to delay or prevent the achievement of the national reconciliation.

11) The lack of the consensus among the Iraqi political forces on common positive principles for the legitimate and peaceful political activities which would enable them to achieve the reconciliation process. Those are represented by:

A- The principle of mutual recognition of the existence and continuation of the all-political forces, and the right to enjoy equal rights and freedom;

B- The principle of peaceful dialogue and the non-resort to violence in solving the problems;

$\mathrm{C}$ - The principle of non-dependence on foreign forces in solving internal problems and adopt internal solutions to internal problems;

D- The adoption of the principle of good will toward others and avoid adopting double standard;

E- The adoption of the principle of distributing the national wealth among all citizens equally;

F- The adoption of the principle of frankness and admitting committing mistakes and present an apology to those who got hurt and compensating them, as a pre-request to the achievement of the reconciliation process and stop the cycle of blood and revenge;

G- The adoption of accepting the amendment of the constitution according to the approved written procedures, because what good for today, would not be good for tomorrow.

Unfortunately, the continuation of the problems of reconciliation without finding real solutions, has led to the broadening and deepening of those problems under the rule of the second Mr. Maliky's government. The worsening of security situation as a result of the prolongation of those problems, and the unwillingness of the gov- 
ernment to find solutions -despite the fact that it had the human and financial resources to solve those problemshave led to the inheritance of those problems by the new government of Mr. Al-Ibady. Consequently, it is natural that, Al-Ibady government is going to suffer badly of the negative results to such a situation.

In September 2014, Mr. Al-Ibady formed the new Iraqi government under a highly complicated and negative circumstance; it has to bear all the negative consequences of the three elected proceeding governments:

- The first negative consequences to deal with, is the loss of more than a third of Iraq's territory, which become under the rule of the (I S I S). This event is considered to be as one of the consequences of leaving the reconciliation process unsolved and the harsh dealing with its components;

- The second negative consequence is to manage the human and financial cost of the military operations to liberate those territories, despite the fact that the new government has found the treasury empty and have to look for new sources to finance its daily needs;

- The third negative consequence is the declining of the prices of oil. It is the only source to finance all aspects of life in Iraq. The government is suffering from dedicating a large sum of money to solve the reconciliation problem, which is considered the most important factor in liberating the occupied territories.

Al-Ibady governmental should realize that, many of what it has desired to achieve, is linked to what will be achieved in the reconciliation process. We need to know that, the in achievement of the reconciliation process, till the present time and after the withdrawal of the American forces, is caused by the negative foreign intervention on one side, and the principal of Quota on the other. These two negative factors are leading to increase the suffering of the Iraqi situation, which represented by:

- The passing of too many legal and constitutional legislations and the unprofessional application especially of those related to the reconciliation which would cause not just stopping to any future achievement in it, but it may cause the sabotage of what previously had been achieved in it, in spite of its limitation;

- The factor of the demands of those who objected to the bases of the formulation of the government and its programs and work accused it of being impartial, bias, and not honest in performing what they want. This kind of thinking would not lead to achieve any agreement between those parties;

- The indecisive governmental interaction with the popular demands accompanied by the ignorance of the committees of the parliament and their irresponsible public statements made by many members of these specialized committees would not help in making any future achievement in the reconciliation process, and sometimes it would backfire through stopping the few works of the reconciliation;

- The foreign support factor to those demands, have led to the formation of many axis and alliances between those who adopted them and the supporting foreign powers. This factor would not only lead to blocking the work of the reconciliation, but it would make Iraq the arena of struggle among these foreign powers. In addition, it would transform Iraqis into agents of implementing the objectives of those foreign powers.

Achieving reconciliation in Iraq requires treating all those factors through direct, serious and frank dialogue between the government and all those opposing parties. The first thing is supposed to be treated is not just achieving the reconciliation, but to correct the whole Iraqi situation, including the state of the political process, the Quota principle which become the most important negative factor which breeds all other negative problems after the official withdrawal of the American forces.

\section{The Problem of Governmental Corruption}

Corruption is pervasive at all levels of government in Iraq. Public survey from transparency international indicates that a majority of public is not satisfied with the government's current efforts in fighting corruption (Ackrman, 2003). Political parties and public servants are considered corrupt and petty corruption is highly institutionalized in backward society (Al Kubaisy, 2000; Al Shiek, 2003).

The danger of governmental corruption could be doubled because of the nature of some of the political principles applied like the Quota principle, which has been laid in Iraq as a basis for the consensual democracy. The practice of this democracy has proved to a blocking democracy rather than consensual democracy. This means that, each party participating in the political process is blocking the efforts made by the other party rather than supporting it and implementing it, as it should be.

The quota principle, which based on ethnicity, religious and sectarian bases and its consensual democracy, considered the ensuring factor of its continuity. This factor could not be abolished or amended in the near future. This fact has added and contributed to new negative effects on the process of building democratic Iraq. The most 
important of these are:

- The great share of corruption has participated in the transformation of the positive feelings of Iraqis into negative one toward their government. This change has been reflected in many peaceful demonstrations and protests in Baghdad and many other major cities since February 2011. If this situation continues with negative respond from the government, it might cause a bad attitude in the people, and might change their confidence in the political regime since the year 2003. Moreover, that what really happened when those peaceful demonstrations and protests, turned into armed confrontations with government forces. It only ended with the invasion of the (ISIS) armed men to the regions of those protested people;

- The manipulation of the deterioration of the security situation as a justification to justify the absence of transparency and oppressing liberties has provided a good environment that contributed to the continuity of corruption and its bad effects on all Iraqi citizens;

- The manipulation of the state of political instability and use it as a justification to the rapid changes in governmental posts. This change is happening to make those officials get richer in order to secure their personal future before they leave their posts and would never be appointed again;

- The general and common rule, says that the high level of salaries and privileges to the high governmental officials restrict their greed and reduce corruption. Nevertheless, in Iraq this rule works the opposite way, it becomes as a motive for more greed and richness to the high governmental officials to offset what they are going to loss when they leave their posts;

- The general and common rule says that the natural desire for all politicians in the world in their reelections is to make more of the good efforts and reduce their corruption. However, in Iraq, this rule works the opposite way, they work on the re election in order to make more thefts and get richer through corruption;

- The bases of corruption gets broader with the increase in the number of ministries and the appointment of high level officials in special degrees as public figures. This has been used to satisfy, as many number as possible of the allies and even those who oppose them. These kinds of act protected by the quota principle and its consensual democracy, which make them, feel secure from being exploited and presented to courts;

- The participation of the high government administrators in the direct political struggle among the interacting political parties, have made them in need to allies and their salaries and privileges could not cover expenditures. They cover them through more financial and political corruption.

In light of all that, it seems that the only mean to fight corruption in Iraq, at the present time, and through the foreseeable future is to combine temporarily between the following basic procedures:

1) The encouragement of individuals and non-governmental organizations (NGO's) on suing those corrupted officials with real legal evidence, and granting them a specified percentage of the regained money. Otherwise, they will have to face legal responsibility if their claims turned out to be false;

2) Grant a broader right to all media, now to uncover the crimes of corruption and corrupted officials, under the condition of having real legal evidence;

3) Provide a broader role and greater freedom to the media in covering corrupt officials, and grant those officials the right to respond through the media and defend their legal rights, if the claims against them turned out to be false;

4) Giving the media the permission to attend and document and televised the court procedures concerning the cases of corruption, to publicized their charges or prove their innocence.

If there is a conclusion to such a research, it should be focused on the fact that, it is very natural for the rebuilding of the state of Iraq is to face many problems, which seems to be solvable. This requires the recognition of its existence first; set its priorities second, and the realization of the necessity of the collective cooperative work to deal with it third.

\section{Conclusion}

In conclusion, the process of rebuilding the state of Iraq since 2003 has faced many problems and the most salient of them are the problems we have discussed in this paper. The problem of national identity is the main \& most important of them because it has given rise to real obstacles, which are the reconciliation \& quota principle. Therefore, we tried in this paper to present alternatives which might help in overcoming those problems. Finally, we believe that solving the problem of national identity in Iraq will lead to solve the problems of reconciliation \& quota principle, which in turn will lead to solve most of Iraq's rebuilding problems. The new situation after June 2014 put the political forces in Iraq in a position facing the same threat. We think it is a perfect time to 
work cooperatively to confront the common enemy and solve those problems.

\section{References}

Ackerman, S.-R. (2003). Corruption \& Government, Causes, Consequences \& Reforms. Translated by Fouad Al-Sorojy, Al-Ahlya for Publishing \& distribution, Jordan-Amman.

Al-Kubaisy, A. (2000). Administrative Corruption. Methodical Visions to Diagnose, Analyze, \& Treat. Arabic Journal of Administration, 20, 1.

Al-Shiek, E. (2003). Corruption \& Reform. Damascus: ARAB Writer's Union.

Annabaa.org (2006) http://WWW.Annabaa.org

Dahl, R. A. (1964). Modern Political Analyses. Englewood: Prentice-Hall, Inc.

Duverge, M. (1958). Institutions politiques et Droit constitutionnel. Location: Presses Universitaires De France.

Edited Book (2009). National Reconciliation. Reality \& the Prospects, Committee Responsible for the Coordination of NGO'S in Iraq in Association with the AL-AMAL Iraqis Society \& the UNDP, Baghdad.

Huntington, S. P. (2004). Who Are We? The Challenges to American National Identity. New York: Simon \& Schuster.

Lijphart, A. (1977). Democracy in Plural Societies. New Haven; Yale University Press.

State Ministry for National Dialogue Affairs. (2007). A Year of Dialogue \& Reconciliation, Baghdad, Iraq.

State Ministry for National Dialogue Affairs. (2008). A Second Year of Dialogue \& Reconciliation, Baghdad, Iraq.

Watts, R. L. (2005). Comparing Federal Systems. Kingston: Institute of Intergovernmental Relation, Queen's University. 